\title{
Identifikasi Bakteri Escherichia Coli pada Air Minum Isi Ulang yang Diproduksi Depot Air Minum Isi Ulang di Kecamatan Padang Selatan
}

\author{
Fathoni Afif ${ }^{1}$, Erly $^{2}$, Endrinaldi ${ }^{3}$
}

\begin{abstract}
Abstrak
Menurut Permenkes No. 492 tahun 2010, air minum berkualitas dinilai dari parameter mikrobiologi adalah tidak ditemukannya bakteri total coliform dan Escherichia coli dalam $100 \mathrm{ml}$ sampel. Menurut beberapa penelitian sebelumnya, banyak depot air minum isi ulang yang memproduksi air tidak sesuai dengan persyaratan secara mikrobiologi tersebut. Tujuan penelitian ini adalah untuk mengidentifikasi kehadiran bakteri Escherichia coli pada air minum yang diproduksi depot air minum isi ulang di Kecamatan Padang Selatan. Penelitian dilakukan di Laboratorium Mikrobiologi Fakultas Kedokteran Universitas Andalas pada sampel air yang didapat dari 13 depot yang tidak melakukan uji kualitas. Jenis penelitian ini adalah deskriptif. Data diperoleh dengan cara observasi dan wawancara langsung. Penelitian mikrobiologi air menggunakan metode Most Probable Number (MPN) yang terdiri dari presumptive test dengan menggunakan media Lactose Broth (LB) dengan metode 3 tabung, confirmative test dengan menggunakan media Brillian Green Lactose Broth (BGLB), complete test dengan menggunakan media endo agar, dan tes identifikasi dengan menggunakan media uji biokimia. Hasil penelitian didapatkan bahwa 10 dari 13 sampel tercemar oleh bakteri coliform dan 2 sampel memenuhi syarat untuk penelitian selanjutnya secara kualitatif. Pada penelitian lanjutan, tidak ditemukan bakteri Escherichia coli namun ditemukan bakteri Pseudomonas aeruginosa.
\end{abstract}

Kata kunci: escherichia coli, depot air minum isi ulang, MPN

\section{Abstract}

According to the Minister Regulation. 492 in 2010, assessed quality of drinking water in microbiological parameters is by the discovery of total coliform bacteria and Escherichia coli in a $100 \mathrm{ml}$ sample. According to some previous studies, many drinking water that produced by the depot does not conform to the microbiological requirements The objective of this study was to identify the presence of the Escherichia coli in drinking water produced by refill drinking water depot in the District of South Padang. Research had been carried out in the Laboratory of Microbiology, Faculty of Medicine, University of Andalas in water samples obtained from 13 depots that don't test the quality. This research was a descriptive. Data obtained by direct observation and interviews. This research used Most Probable Number (MPN) test for the microbiological of the water that consist of presumptive test using Lactose Broth (LB), confirmative test using Brilliant Green Lactose Broth (BGLB), complete test using endo jelly media, and identification test using biochemistry test. The results showed that 10 of 13 samples contaminated by coliform bacteria and 2 samples eligible for further research that show there is a Pseudomonas aeruginosa .

Keywords: escherichia coli, refill water depot, MPN

Affiliasi penulis :1.Pendidikan Dokter FK UNAND (Fakultas Kedokteran Universitas Andalas Padang, 2. Bagian Mikrobiologi FK UNAND, 3. Bagian Kimia FK UNAND.

Korespondensi : Fathoni Afif, E-mail :fathoni.afif05@gmail.com, Telp: 0812-75491771

\section{PENDAHULUAN}

Sekitar tiga per empat bagian tubuh manusia terdiri dari air, menjadikan air sebagai zat terpenting untuk kebutuhan dasar agar berlangsungnya kehidupan. Air selain bermanfaat bagi manusia, juga 
merupakan media yang baik untuk kehidupan bakteri. Bakteri ini dibedakan menjadi dua, yaitu bakteri patogen dan bakteri non-patogen. Bakteri patogen dapat menyebabkan penyakit dengan keluhan diare seperti disentri, tipus, dan kolera, melalui air yang diminum. Beberapa contoh bakteri patogen adalah Shigella dysentriae, Salmonella typhi, Salmonella paratyphi. Untuk bakteri non-patogen contohnya dari golongan bakteri Fecal streptococci, Iron bacteri, dan Actinomycetes. ${ }^{1,2}$

Air yang aman untuk diminum adalah air bersih yang harus memenuhi persyaratan secara fisika, kimia, radioaktif dan mikrobiologi yang telah ditetapkan oleh pemerintah. Secara mikrobiologi, salah satu syarat air bersih yang dapat dikonsumsi adalah tidak ditemukannya Escherichia Coli dalam $100 \mathrm{ml}^{3}$ Escherichia Coli juga termasuk bakteri yang dapat menyebabkan keluhan diare. ${ }^{4}$

Sekitar tahun 1999, mulai bermunculan usaha depot air minum isi ulang. Depot air minum adalah usaha industri yang melakukan proses pengolahan air baku menjadi air minum dan menjualnya langsung kepada pembeli dengan kemasan berupa galon. Untuk menjamin kualitas produk air minum yang dihasilkan, maka depot air minum diwajibkan untuk melakukan pengujian kualitas produk di Laboratorium Pemeriksaan Kualitas Air yang ditunjuk oleh Pemerintah Kabupaten/Kota atau yang terakreditasi, dilakukan sekurang-kurangnya dalam 6 (enam) bulan sekali. Hal ini juga dilakukan untuk mendukung terciptanya persaingan usaha yang sehat dan sebagai upaya dalam memberi perlindungan kepada konsumen. ${ }^{5,6}$ Data dari Dinas Kesehatan Kota Padang tahun 2011 terdapat sebanyak 604 depot air minum isi ulang, hanya 7 dari 32 depot air minum isi ulang di Kecamatan Padang Selatan yang melakukan uji kualitas produk sesuai Keputusan Menteri Perindustrian dan Perdagangan no. 651 tahun $2004{ }^{7}$

Depot air minum di Indonesia pernah dicap menghasilkan air minum yang tidak berkualitas. Adanya E. coli pada sampel air minum mengindikasikan bahwa air minum tersebut bisa saja tercemar oleh bakteri patogen yang dapat menyebabkan keluhan pada sistem pencernaan seperti diare. Diare adalah satu dari banyak penyakit lainnya yang dapat disebabkan oleh buruknya kualitas air minum secara mikrobiologis. ${ }^{8}$ Diare termasuk dalam sepuluh penyakit yang banyak terjadi di Kota Padang. Tercatat sebanyak 12.744 kasus diare yang terjadi di Kota Padang berdasarkan profil kesehatan Kota Padang tahun 2010. Kecamatan Padang Selatan adalah kecamatan dengan morbidity rate teringgi di Kota Padang dengan nilai morbidity rate sebesar 29. Hal inilah yang mendasari perlu dilakukan penelitian untuk mengetahui apakah air minum yang diproduksi depot air minum isi ulang di Kecamatan Padang Selatan aman untuk diminum atau tidak teridentifikasi keberadaan bakteri $E$. coli yang merupakan salah satu syarat mikrobiologis untuk air minum. ${ }^{7}$

\section{METODE}

Ini adalah penelitian deskriptif laboratorium. Pemeriksaan sampel dilakukan di Laboratorium Mikrobiologi Fakultas Kedokteran Universitas Andalas Padang pada dari Desember 2013 sampai April 2014. Populasi meliputi seluruh depot air minum isi ulang yang tidak melakukan uji kualitas air minum di Kecamatan Padang Selatan berdasarkan data dari Dinas Kesehatan Kota Padang tahun 2011. Jumlah depot per November 2011 yang terdapat disana sebanyak 25 depot air minum isi ulang. Sampel penelitian ini sebanyak 13 depot air minum isi ulang yang didapat dari menggunakan rumus Slovin. Penentuan 13 dari 25 sampel dilakukan dengan metode simple randomized sampling yaitu dengan cara memberikan nomor 1-25 pada populasi depot, lalu diambil beberapa nomor secara acak sebanyak 13 buah. Nomor yang terpilih tersebut dijadikan sampel untuk penelitian ini. Pengambilan sampel secara langsung dengan membeli air minum isi ulang pada depot air minum isi ulang yang terdapat di Kecamatan Padang Selatan, Padang. Dilakukan observasi terhadap beberapa faktor seperti sumber air baku, kondisi depot, kebersihan pekerja, dan cara penanganan galon yang dibawa pembeli sebelum dilakukan isi ulang. Lalu dilakukan pemeriksaan mikrobiologi di Laboratorium Mikrobiologi Fakultas Kedokteran Unand dengan menggunakan metode Most Probable Number (MPN) yang terdiri dari presumptive test dengan menggunakan media Lactose Broth (LB) dengan metode 3 tabung, confirmative test dengan menggunakan media Brillian Green Lactose Broth (BGLB), complete test dengan 
menggunakan media endo agar dan tes identifikasi dengan menggunakan media uji biokimia.

HASIL

Penelitian dilakukan dengan mengambil sampel air depot air minum isi ulang di Kecamatan Padang Selatan dari Desember 2013 - April 2014.

\section{Tes Presumtif}

Tabel 1. Hasil tes presumtif

\begin{tabular}{ccccc}
\hline No & \multicolumn{3}{c}{ Tes Presumtif } & \multicolumn{2}{c}{ Total Coliform } \\
Sampel & 10cc & 1cc & 0,1cc & (MPN) \\
\hline 1 & ++ & ++ & - & 21 \\
2 & +++ & - & - & 23 \\
3 & - & - & - & 0 \\
4 & - & + & - & 3 \\
5 & +++ & + & - & 43 \\
6 & - & - & - & 0 \\
7 & ++ & - & - & 9 \\
8 & ++ & + & - & 18 \\
9 & +++ & + & - & 43 \\
10 & + & - & - & 4 \\
11 & +++ & ++ & + & 150 \\
12 & +++ & +++ & + & 460 \\
13 & - & - & - & 0 \\
\hline Keterangan :+ : Terdapat gelembung udara & \\
\multicolumn{5}{c}{ di dalam tabung Durham } \\
& $-:$ & Tidak terdapat gelembung udara
\end{tabular}

Berdasarkan Tabel 1 di atas, didapatkan 35 dari 117 tabung yang menunjukkan hasil positif dan 10 dari 13 depot air minum di Kecamatan Padang Selatan yang menjadi sampel menghasilkan air minum yang tidak aman untuk dikonsumsi sesuai Permenkes no. 492 tahun 2010 mengenai persyaratan kualitas air minum. Untuk penelitian yang bersifat kualitatif, hanya sampel 11 dan 12 yang memenuhi persyaratan untuk dilanjutkan ke uji konfirmatif

\section{Tes Konfirmatif}

Tabel 2. Hasil tes konfirmatif

\begin{tabular}{ccc}
\hline $\begin{array}{c}\text { No } \\
\text { Sampel }\end{array}$ & Tes Konfirmatif & Keterangan \\
\hline 11 & Positif & Lanjutkan \\
12 & Negatif & Tidak dilanjutkan
\end{tabular}

Berdasarkan Tabel 2, tes konfirmatif yang bersifat kualitatif hanya dilakukan pada sampel yang menunjukkan hasil positif setidaknya di dalam 2 seri pengenceran. Sampel yang digunakan adalah sampel dengan pengenceran tertinggi pada tes presumtif yaitu pada tabung dengan sampel $0,1 \mathrm{cc}$. Hasil positif pada uji konfirmatif ini memastikan bahwa terdapat bakteri coliform pada sampel yang digunakan. Sampel no 11 dijadikan sampel selanjutnya untuk tes lengkap

\section{Tes Lengkap}

Setelah ditanamnya sampel no. 11 ke endo agar untuk diinkubasi, didapatkan pertumbuhan koloni bakteri yang berwarna merah muda namun tidak menghasilkan warna metalik jika didiamkan pada suhu kamar. Sampel ini dilanjutkan ke pemeriksaan berikutnya.

\section{Tes Identifikasi}

Tabel 3. Hasil tes identifikasi

\begin{tabular}{|c|c|c|c|c|}
\hline \multicolumn{3}{|c|}{ TSIA } & \multirow{2}{*}{$\begin{array}{c}\text { Simmon } \\
\text { Citrate }\end{array}$} & \multirow{2}{*}{$\begin{array}{l}\text { Sem } \\
\text { Solic }\end{array}$} \\
\hline Slant & Butt & $\mathrm{H}_{2} \mathrm{~S}$ & & \\
\hline$R$ & $\mathrm{R}$ & - & + & + \\
\hline
\end{tabular}

Tabel 3 didapatkan kesimpulan bahwa koloni yang tumbuh adalah bakteri Pseudomonas aeruginosa. Bakteri ini tidak dapat memfermentasikan glukosa dan laktosa dibuktikan dengan pengujian TSIA. Bakteri ini dapat menggunakan sitrat dan juga memiliki flagel.

Hasil penelitian, pada tes presumtif didapatkan sepuluh dari tiga belas sampel atau $76,92 \%$ tidak memenuhi persyaratan secara mikrobiologi yang telah ditetapkan oleh Peraturan Menteri Kesehatan No. 492 Tahun 2010. ${ }^{7}$ Dari sepuluh sampel penelitian yang positif, hanya dua yang memenuhi syarat untuk dilakukan uji secara kualitatif. Setelah dilakukan uji selanjutnya, satu dari dua sampel menunjukkan hasil positif pada tes konfirmatif dan menunjukkan pertumbuhan bakteri Pseudomonas aeruginosa.

Adanya hasil positif yaitu adanya gas di dalam tabung pada tes presumtif, dapat diduga bahwa air sampel tersebut mengandung coliform dan tidak aman untuk diminum. Hasil tes presumtif ini juga dapat 
digunakan untuk menghitung jumlah perkiraan terdekat bakteri coliform yang ada di air.

Beberapa faktor yang dapat mempengaruhi kualitas produk air minum yang dihasilkan adalah air baku, kebersihan operator, penanganan terhadap wadah pembeli, dan kondisi depot. Semua depot air minum yang menjadi sampel menggunakan air baku yang berasal dari Gunung Talang, Solok, dan sepuluh dari tiga belas depot menunjukkan hasil positif yang berarti air baku yang digunakan berkualitas buruk.

Selain air baku, faktor lainnya yang dapat mempengaruhi kualitas air minum adalah kebersihan dari operator yang menangani dan melakukan pengisian terhadap wadah yang dibawa oleh konsumen. ${ }^{8}$ Hanya beberapa depot yang memiliki operator yang sadar akan kebersihan baik itu lingkungan dan proses kerjanya maupun kebersihan diri mereka sendiri. Salah satu bentuk menjaga kebersihan diri sendiri adalah dengan mencuci tangan sebelum menangani wadah yang dibawa konsumen, gunanya adalah untuk mengurangi kemungkinan terjadinya kontaminasi, namun tidak satupun dari tiga belas operator pada depot air minum isi ulang di Kecamatan Padang Selatan yang dijadikan sampel melakukannya.

Penanganan terhadap wadah yang dibawa konsumen juga berperan penting dalam mempengaruhi kualitas air. Sekalipun kualitas air yang dihasilkan bagus namun penanganan terhadap wadah tidak diperhatikan, akan dapat mengurangi kualitas air karena dapat terjadi kontaminasi dari luar proses produksi. Penanganan yang baik dilakukan dengan pencucian menggunakan berbagai jenis deterjen khusus yang kita sebut dengan tara pangan (food grade) dan air bersih dengan suhu berkisar $60-85^{\circ} \mathrm{C}$, lalu dibilas dengan air produk secukupnya utntuk menghilangkan sisa deterjen yang digunakan untuk mencuci. ${ }^{5}$ Semua depot yang menjadi sampel di Kecamatan Padang Selatan tidak melakukan penanganan terhadap wadah yang dibawa pembeli sesuai dengan peraturan tersebut. Cara yang umum digunakan kebanyakan depot sekarang adalah menyikat dan membilas dengan air produk setelah itu langsung diisi. Di Kecamatan Padang Selatan, sebanyak $38,46 \%$ sampel melakukan penyikatan serta pembilasan dan didapatkan 60\%-nya menghasilkan air minum dengan kualitas sesuai peraturan sedangkan selebihnya menunjukkan hasil positif. Sementara depot yang hanya melakukan pembilasan, yaitu sebesar 46,15\%, semua air minum yang dihasilkan mengandung bakteri coliform. Depot selebihnya yang tidak melakukan penyikatan dan pembilasan terhadap wadah pembeli didapatkan mempunyai kandungan total coliform yang jauh lebih tinggi dibandingkan sampel positif lainnya.

Tidak semua depot yang menjadi sampel memberikan tisu beralkohol yang biasa digunakan untuk membersihkan bagian mulut galon padahal alkohol dapat membunuh bakteri sehingga dapat menurunkan tingkat kontaminasi dari luar terutama pada pengguna yang menggunakan dispenser. Hanya lima depot yang memberikan tisu alkohol kepada konsumen, tiga dari lima depot menghasilkan kualitas air minum yang bagus sedangkan dua lainnya menunjukkan hasil positif pada pemeriksaan.

Faktor lain yang tidak kalah penting yang dapat mempengaruhi kualitas air minum yang diproduksi adalah kondisi depot air minum itu sendiri. Lokasi usaha ini harus terbebas dari pencemaran yang berasal dari debu sekitar depot dan tempat-tempat lain yang berpotensi mengakibatkan pencemaran. ${ }^{5}$ Depot yang bergabung dengan aktifitas lain sebanyak $23,08 \%$ dari sampel, hal ini dapat menyebabkan pencemaran dari lingkungan sekitar. Selain itu juga perlu diperhatikan kebersihannya. Delapan dari tiga belas depot tidak bergabung dengan aktifitas lain dan terlihat terawat, tiga atau $37,5 \%$ diantaranya menghasilkan air minum dengan kualitas bagus dengan tidak ditemukannya bakteri coliform. Depot yang sudah tersendiri namun tidak terawat sebanyak $15,38 \%$ dari sampel menunjukkan hasil positif mengandung bakteri coliform. Depot yang bergabung dengan aktifitas dan tidak terawat menunjukkan hasil positif dan mengandung bakteri coliform dalam jumlah yang banyak.

\section{KESIMPULAN}

Sebanyak 10 dari 13 sampel yang diproduksi 13 depot air minum isi ulang di Kecamatan Padang Selatan tidak memenuhi persyaratan secara mikrobiogi yang telah ditetapkan oleh Peraturan Menteri Kesehatan No. 492 Tahun 2010. Hasil 
pemeriksaan laboratorium menunjukkan bahwa 2 sampel memenuhi persyaratan untuk dilakukan uji kualitatif. Satu dari 2 sampel uji kualitatif menunjukkan hasil positif dan menunjukkan pertumbuhan koloni bakteri. Tidak ditemukan bakteri Escherichia coli sehingga kemungkinan ditemukannya bakteri patogen enterik lainnya lebih rendah. Hasil pemeriksaan biokimia menunjukkan adanya bakteri Pseudomonas aeruginosa pada sampel tersebut.

\section{UCAPAN TERIMA KASIH}

Penulis mengucapkan terima kasih kepada dr. Erly, Sp.MK dan Drs. Endrinaldi, MS selaku penulis kedua dan ketiga untuk waktu dan ilmu yang diberikan kepada penulis sehingga dapat diselesaikannya karya ilmiah ini yang diharapkan dapat bermanfaat bagi penulis dan para pembaca.

\section{DAFTAR PUSTAKA}

1. Untung, Onny. Menjernihkan air kotor. Jakarta: Puspa Swara Chandra B; 2004.
2. Dwidjoseputro D. Dasar-dasar mikrobiologi. Jakarta : Djambatan; 2005.

3. Departemen Kesehatan RI. Peraturan Menteri Kesehatan No. 492 Tahun 2010 tentang Persyaratan Kualitas Air Minum. 2010.

4. Simadibrata M, Daldiyono. Diare akut. Dalam: IImu Penyakit Dalam Jilid 1. Jakarta : Interna Publishing; 2009. hlm. 548-56.

5. Departemen Perindustrian dan Perdagangan RI. Keputusan Menteri Perindustrian dan Perdagangan No. 651 Tahun 2004 tentang persyaratan teknis depot air minum dan perdagangannya. 2004.

6. Kusnaedi. Pengolahan air gambut dan air kotor untuk air minum. Jakarta: Penebar Swadaya; 2006.

7. Departemen Kesehatan RI. Profil Kesehatan Indonesia 2010. Jakarta: Kementrian Kesehatan Republik Indonesia. 2011.

8. Suriawiria U. Mikrobiologi air dan dasar-dasar pengolahan buangan secara biologis. Bandung: Penerbit Alumni; 2008. 